\title{
The Socialist Popularization of Science in America, 1901 to the First World War
}

\author{
GEORGE COTKIN
}

THROUGHOUT MUCH OF THE nineteenth century the ascendent star of science was closely tied to the rise of the middle class. Science reflected their optimism and aided them in understanding a world and society in constant motion. The middle class embraced science in a hearty manner and as a labor of love they sought to popularize it in America. By the turn of the century, the middle class enthusiasm for popularization had abated somewhat, but science was still being pursued and popularized with great ardor by others. Only now the group most enamored of science, and certain that its rise was tied to the prestige and power of science, was the socialist movement, the self-appointed sentinel of the working class. No less than the middle class, the socialist intellectuals sought to ground their discourse in scientific language and to make the fruits of science readily available to a wide audience. The great revolutions in science-the Copernican, Newtonian, and Darwinianbecame the subject matter for socialist popularizers of science. Their tale was simple: Marxism was a science, a scientific revolution in social thought, that would usher in not only a new world-view, but a new society, a new age.

Science served as a powerful symbol and "attitude of mind" for nineteenthcentury Americans. As the handmaiden of technology, science was changing the physical landscape of America in the era of the railroad, telegraph, steam, and electricity. For most Americans, science was a symbol easily reconciled with the prevalent assumptions of societal progress. ${ }^{1} \mathrm{~A}$ scientific knowledge, according to geologist Clarence King in his Catastrophism and the Evolution of Environment (1877), would be "a means of clearing away the endless rubbish of false ideas from the human intellect, for the lifting of man out of the dominion of ignorance." 2

Yet science was more than an object of veneration or a description for new technologies; it was a explanatory and normative concept as well. While science could be blamed for inaugurating an era of bewildering change and chaos, it could at the same time organize apparent chaos into a

Mr. Cotkin is a member of the Department of History, California Polytechnic State University 
comprehensible and progressive doctrine. Faced with a confusing reality, Americans hoped that the synthesis offered by science might lead them out of the morass. The powerful appeal of Herbert Spencer to a generation of Americans was precisely in his promise of a method and synthesis that would calm the seemingly turbulent waters of change. ${ }^{3}$ Either through Spencer or other apostles of science, Americans hoped that the method of science would allow them "to put the universe into [their] pockets," a metaphor at once both reassuring and possessive. ${ }^{4}$

Science served as a normative concept for nineteenth-century Americans; it became the intellectual coin of the realm. ${ }^{5}$ Whereas Henry James, Sr. as a young man in 1842 could ask Emerson whether he should "learn science and bring myself into men's respect", by the second half of the century-and for at least one of James' sons - the domination of science had rendered the question obsolete. ${ }^{6}$ No educated man could afford, both professionally and personally, to be without the scientific "attitude of mind." As John M. Coulter told the graduates of the University of Michigan in 1900, scientific training "is essential in every well-balanced education." 7 In addition, science had come to define the norms of society: a scientific way of viewing the world, of regulating one's personal habits, of deciding truth and value, these were the common themes in the style and thought patterns of middle-class, educated Americans in the late nineteenth century. ${ }^{8}$

The confident strut of science was in perfect stride with the optimism and power of middle-class America. The equation was simple: science equalled power. This perspective was grasped by the ambitious university presidents of the nineteenth century who incorporated it into their college curricula. Science became a fitting subject for the academies and was, in turn, professionalized. The university curriculum opened up and developed the social sciences along a scientific model. Professionally trained social scientists employing the scientific methods of research, it was imagined, would dominate the nation's intellectual and social life. Science came "to epitomize," in Thomas Haskell's precise formulation, "the very essence of the professional idea-expert authority, institutionally cultivated and certified." In short, the university would, through scientific expertise, engage in the construction of normative values for the American public. ${ }^{9}$

The entry of science into the domain of the professional academy came only after it has already achieved an exalted place in the public sphere. Throughout the nineteenth century, the American public had flocked to lyceums to hear lecturers explicate the wonders of modern science. As demanded by their public, lyceum lecturers transformed science into entertainment. ${ }^{10}$ In lyceums and lecture halls around the country, serious scientists and pretenders demonstrated the practical, and most appealingly, the curious effects of science. The lyceum lecturer who offered the public a brief scientific education appealed to what historian Margaret Rossiter has called the "cult of self-improvement." In the Jacksonian days of the common man, science was a 
leveling tool of the democratic spirit; it promised equality and progress. The popular lecture, then, was entertainment, education, and ideology combined. ${ }^{11}$

While the lecture remained a compelling method for the diffusion of science, its efficacy was undermined by the rise of Darwinian science. Unlike a discussion of electricity which might include numerous mechanical devices to entertain the crowd, the explication of evolutionary science was more conducive to the printed word. After the Civil War, a veritable "obsession with disseminating the printed page," as Barton Bledstein phrases it, through a plethora of new publications, afforded a new means to communicate science to a burgeoning American reading public. ${ }^{12}$

The crucial chapter in the popularization of science and its concomitant development as a normative symbol for middle-class America was written in 1872 when Edward Livingston Youmans published the first issue of his Popular Science Monthly (PSM). Originally conceived as a platform for Youmans to bring Herbert Spencer's The Study of Sociology before the American public-“what we want," he wrote Spencer, are your "large, organizing ideas" - the journal soon came to speak for the autonomy and cultural credibility of science. ${ }^{13}$ Youmans set no limits for science: its scope was all inclusive and breathtaking. The goal of diffusing scientific knowledge was "the next great task of civilization." In keeping with the republican tradition of self-improvement through education, the PSM appealed "not to the illiterate, but to the generally educated classes" who wished to achieve "self-instruction in science." 14 The success of Youman's effort and the middle-class' hunger for scientific knowledge was reflected in the magazine's circulation figures. In 1886, Youmans could boast of 18,000 copies in circulation, high figures for an expensive and, at times, sophisticated journal. ${ }^{15}$

By 1900, now under the editorial direction of the distinguished psychologist J. McKeen Cattell, the subscription list of the PSM had dwindled, until in 1915 the magazine was reporting yearly losses of $\$ 10,000$. The format of the PSM changed and now featured articles on how-to-build-it-yourself gadgets and eschewed discussions of theoretical science. ${ }^{16}$ Numerous historians have connected the decline of the PSM with a diminution of middle-class enthusiasm for scientific information. The explanations for this presumed decline are legion: professional disdain for scientic popularizing; the everincreasing specialization and sophistication of the sciences; the decline of cosmic syntheses such as Spencer's; a waning interest in nature study as urbanization increased; and, finally, the increasing tempo of religious doubts concerning the direction of science. ${ }^{17}$

Despite all of these explanations, science was not a dead issue in the American mind. Noting this apparent paradox, Ronald Tobey finds that while popular science was supposed to be in decline, the best known theorists of the progressive era were basing their exegeses on scientistic premises, as 
revealed by a cursory glance at Herbert Croly's The Promise of American Life (1909) and Walter Lippmann's Drift and Mastery (1914). ${ }^{18}$

The paradox dissolves once one accepts the view that science remained a powerful rhetorical and explanatory device for intellectuals. However, no longer would the accolades paid to science come only from the middle class: the prestige of science would now be appropriated by the working class. As the socialist movement adopted science, they also established an institutional and literary framework for the propagation of scientific ideas.

The continued dissemination of a "culture of science" after 1900 was made possible by the meteoric rise of an American socialist movement. Dominated by intellectuals conversant with science and convinced of its value for their comrades, the Socialist Party of America (SPA) offered an institutional framework through which science could be communicated to American workers. ${ }^{19}$ After more than thirty years of isolation and sectarian squabbles, American radicals found some common ground and formed the Socialist party in 1901. By 1912, party membership was over 118,000 strong. In that same year, party presidential candidate Eugene V. Debs polled nearly 900,000 votes and over 1,200 socialists were voted into offices around the country. The party's electoral successes were mirrored by their propaganda victories. Socialism was communicated to the faithful through over 300 partysponsored publications; the Appeal to Reason, published out of Girard, Kansas, boasted 761,747 paid subscribers in 1913. ${ }^{20}$

The mass of statistics collected by historians purportedly tracing the party's electoral growth and decline have tended to obscure James Green's fine observation that socialism "was an educational as well as a political force." 21 American socialist intellectuals perceived their educational work as a solemn duty, one no less important than electoral or trade union agitation; in fact, they permitted no such division of labor. The popular socialist lecturer Arthur M. Lewis went so far as to argue that "the chief avenue to the realization of their [socialist] ideals must be through proper education." 22 Knowledge helped to enlighten the worker, it was generally acknowledged, so that he or she would vote socialist or learn how to organize a trade union. Writing in the premiere issue of The Agitator, Jay Fox announced that "Knowledge is the most dangerous thing in the world."' ${ }^{23}$ Lena Morrow Lewis, a well-known socialist agitator, in an essay "The Materialist Basis of Education," shortened Fox's equation to read: "Knowledge is Power." ${ }^{44}$ For many socialists the most powerful form of modern knowledge was scientific. In words which few radicals would question, an editorial writer in the popular theoretical journal International Socialist Review exclaimed that "scientific discoveries are weapons in the working class' arsenal." Furthermore, he contended that "There is no work that will yield such rich returns in valuable information for the Socialist worker as the study of natural science." 25

American socialists' love affair with science had its roots in the tradition of European Marxism and within American culture. A positive view towards 
science was early predominant within European Marxism. After all, Marx and Engles labeled their socialism "scientific" both to set it off from opposing varieties of socialism and to give to their theory a naturalistic identity. ${ }^{26} \mathrm{As}$ confirmed believers in the enlightening power of knowledge, education and science, Marx and Engels welcomed Darwinism and sought to use it to validate socialism. Thus did Marx write Lasalle in 1861: "Darwin's book is very important and serves me as a basis in natural science for the class struggle in history." 27 In this same vein, American socialist publisher Gaylord Wilshire was quite serious when he stated, "To be called unscientific is about the greatest insult that can be hurled at a socialist." 28

The presumed connection between Darwin's natural science and Marx's science of society became ubiquitous and went nearly unquestioned within European and American Socialist circles. In his biography of Karl Marx, John Spargo, a well-known socialist writer, made frequent reference to Marx and Darwin as paired scientists: "Darwin explained man's being and Marx explained his social institutions." ${ }^{29}$ Joseph Cohen stressed, in his popular Socialism for Students, that "proletarian science, evolution and revolution are twin forces." In short, Cohen found that "Science and socialism belong together.", 30

The sense that "science and socialism belong together" grew out of the American "culture of science" environment. American socialists naturally turned in this environment to science as the mode and subject of their discourse. At the same time they hoped to appropriate the tradition and cultural prestige of science for their cause. American socialists did not simply cite the well-known and respected names of scientists or "scientific philosophers" such as Darwin, Wallace, DeVries and Spencer; they invoked them. The argument from authority, heavily dependent upon analogy, was assumed to make socialism's premises scientific. Thus, when at the turn of the century the Dutch botanist Hugo DeVries' mutationstheorie questioned the gradualistic assumptions central to Darwinism without undermining Darwinism's general outlines, American socialists immediately flooded their periodicals with arguments based upon the analogy that just as new species of plants were literally born overnight, so too could new societies quickly be instituted through revolution. ${ }^{31}$ In his article, "Evolution by Mutation," Algie M. Simons asked American socialists to note "how closely" DeVries' mutationstheorie "fits in with the socialists' doctrine of the class struggle, according to which there is long period of slow growth with slight variations (or reforms) followed by a sudden change of social character (called revolution) brought about by the accession of a new social class to power." 32

While analogy and authority gave to socialist discourse a sense of confidence, the individual socialist who turned to science often encountered a blissful transcendence. As Irving Howe and David Hollinger have demonstrated, immigrant working-class Jews embraced socialism and science because these concepts lifted them from the confining ghetto of tradition and transported them into a cosmopolitan world. ${ }^{33}$ The human experience, 
through socialism or science, was universalized. Though not a socialistalthough he was reared in that milieu-philosopher Morris R. Cohen sought to escape the prison of the Lower East Side by absorbing the tradition of science. According to David Hollinger, for Cohen

science aimed, by definition, to enter a dialogue with the most universal and timeless segments of experience. Science sought truth of a sort that would command assent from persons of any national, religious, or ethnic background, it was concerned with propositions that were in no way culture-bound. ${ }^{34}$

The same view could be proffered from a Marxian perspective. Class and ethnic divisions obscured reality but an understanding of science and its laws brought an individual into the proper consciousness while allowing him to identify with the forces of historical progress. This identification took on millennial connotations, as when Arthur Lewis stated:

There is every ground for believing that if the scientific knowledge already achieved could be made the common property of the mass of men, it would amply suffice for the solution of the great majority on our social problems and launch the human race in a society which would in some measure correspond to the millenial [sic] dreams of poets and prophets, who have had visions of the golden age and the brotherhood of man. ${ }^{35}$

The socialist faith in science and its power to liberate and dominate discourse was sincere; no less real was their zeal to communicate their findings to the working class. No matter how deep and abiding the socialist commitment to education might be, the success of their endeavor had to await the development of an institutional apparatus capable of disseminating such information. Desire and possibility were joined by the rise to preeminence of the Charles H. Kerr Publishing Company of Chicago. Now socialist interpreters and popularizers of science had a forum.

Originally founded in 1886, the Kerr Company had long been associated with radical causes such as free thought and the People's Party. By 1899 the company had become connected with the Social Democracy led by Eugene Debs and Victor Berger. From this point on, and especially after the founding of the SPA in 1901, the Kerr Company published books considered to be useful to the socialist cause. The company at this time was transformed into a cooperative, and socialists around the country were urged to become shareholders. Of course, as the company admitted, "no dividends were paid or promised." The money raised in this manner was used to finance the influential theoretical journal International Socialist Review and to publish books and pamphlets on socialism. ${ }^{36}$

In the first few years of affiliation with the socialist movement, the Kerr Company published rather predictable titles by such socialist stalwarts as Engels, Karl Kautsky, and Wilhelm Liebknecht. ${ }^{37}$ As early as 1903, however, the chairman of the company expressed dissatisfaction with the narrow range of the firm's offerings. Rather than publishing new and daring works on 
socialism adapted for an American audience and written by American theoreticians, the firm was simply making the classics of socialism available in cheap editions for American readers. While the company never negated the importance of this venture, they clearly wished to expand the scope of their publications. But the board of directors realized that experiments in publishing were both risky and costly. Before the Kerr Company could branch out, it had to raise additional operating capital.

In 1904, after two thirds of the stockholders voted to issue an additional 4,000 shares of stock which increased the company's capital from $\$ 10,000$ to $\$ 50,000$, the Kerr Company could at last "make the most important announcement since the organization" of the firm. With financing secured, the company now went ahead with plans to publish a "Library of Science for Workers." Such a series written in a clear manner, the Company concluded, would have a high propaganda value: once a worker learned how science explained the world's development, he would then be "ready to become a socialist." 38

The first volume published in the series was Wilhelm Boelsche's The Evolution of Man (190'). The choice was a wise one. A successful popularizer of Darwin and Germany, Boelsche wrote in an elegant manner, and his work was ably translated by the American socialist theoretician and apostle of science, Ernest Untermann. Like many of the volumes in the new series, Boelsche's was not overtly socialistic or even materialistic-a testament to the socialist faith in the importance of science. While Boelsche admitted that he directed his volume towards the common man, he rejected any class spirit in science; what followed was a straightforward account of man's evolution. Boelsche struck a familiar note to socialist ears when he said that to be considered educated one must acquire a knowledge of science and especially of the "theories concerning the descent of man." 39

Boelsche's slim volume sought to be comprehensive; he managed to include discussions of the missing link-which he argued was closely related to Pithecanthropus-Haeckel's recapitulationist theory of embryonic development, and the inheritance of acquired characteristics, which Boelsche and most European theorists of social democracy still defended. Boelsche and the other socialist and materialist writers whose works appeared in the series considered the idea of divine creation to be specious, accepted natural selection while stressing man's ethical and cooperative spirit in directing adaptation, and cited the positive role played by man's intelligence in the struggle for existence. ${ }^{40}$

In common with Boelsche's The Evolution of Man, the other translated volumes in the "Library of the Science for Workers" did not develop explicit Marxian arguments. According to its advertisements, R.H. France's Germs of Mind in Plants (1905) was considered worthy of recommendation to workers because it undermined the ruling-class notion "that the mind of man is something unique in the universe, governed by laws of its own that have no 
particular connection with physical laws." However, "modern science” had proven, as illustrated in France's work, that man, plants, and animals all receive sense impressions, act upon them, and modify their environment. ${ }^{41}$ The above appeared only in advertisements; in the book itself the only explicit socialist message was a profession from the volume's translator Algie $\mathbf{M}$. Simons to the effect that science must be popularized because it was of an "essentially revolutionary character." The remainder of Simons' brief introductory note recounted his boyhood love of nature and early experiences "with the field and forest." 42

Not all of the science volumes published by Kerr were translations of works by European popularizers of materialist science. Chicago technical highschool teacher J. Howard Moore published The Law of Biogenesis (1914) in which he analyzed physical and mental recapitulationist theory. The essence of the volume was captured in Moore's definition of biogenesis: "Every organism in its individual development repeats the life history of the race to which it belongs." 43 In her introduction to the volume, socialist Mary Marcy strained to find political content in Moore's thesis. She thought Moore's definition of biogenesis useful for solving "unexplained mysteries," and hoped that the volume would help individuals to recognize and redirect old instincts in ways that would help them adapt better to "the environment of today." 44

One did not have to strain much to grasp the radical intent behind Ernest Untermann's contribution to the series, Science and Revolution (1905). In simple, direct, and exhortatory language, Untermann drew out the revolutionary implications of modern science. As interpreted by Untermann, modern science supported socialism. What is worth noting is that his volume alone, of the seven first published in the "Library of Science for Workers" collection, lived up to the series editors' intentions: to produce works that would prove that "science and socialism belong together." Such a message was present in the other volumes only if read from an already well-informed and rigid Marxian perspective. Without explicit introductions to the volumes drawing out the radical implications of each work, one can only wonder at the success of these works in converting readers to a socialist position, though the volumes certainly succeeded in providing clear and concise expositions of science.

The Kerr Company, though clearly the leader, was not alone in supporting the dissemination of science for a working-class audience. The Comrade Publishing Company in 1905, in addition to offering copies of Marx's Capital and Critique of Political Economy and Morris Hillquit's standard History of Socialism in the United States, advertised inexpensive editions of Darwin's Descent of Man and Origin of Species. ${ }^{45}$ An advertisement in the Chicago Weekly Socialist headlined "Bargain Books" told readers that they could obtain cloth copies of both of Darwin's volumes for only $\$ .50{ }^{46}$ Even the Masses got into the habit of pushing books on science when its initial editor 
Thomas Seltzer translated Wilhelm Ostwald's important work, Natural Philosophy. ${ }^{47}$

The national scope of socialist interest in popularizing and interpreting science may be further suggested by the career of Walter Thomas Mills. A popular orator at socialist encampments in the southwest, Mills was described as a "brilliant teacher" and "brilliant speaker" by Oscar Ameringer, who also remembered him as "one of the last Victorians of the Spencer, Tyndall, and Huxley breed." 48 Mills' textbook The Struggle for Existence (1904) went through many editions and reputedly sold over half a million copies. His work was heavily dependent on Darwin, Wallace, Haeckel, Romanes and the leading evolutionists of his day. Organized in the genetic manner common to the scientific historians of that era, Mills showed how the course of evolutionary development pointed inevitably in the direction of socialism. In this accessible and easily understood volume, each chapter was followed by study questions; it no doubt brought many southwestern radicals into contact with currents then swelling in science, history, and sociology. ${ }^{49}$ An advertisement in the radical journal the Miners' Magazine described The Struggle for Existence as "the most complete and readable application of the scientific discoveries of Darwin, Huxley, Spencer, Morgan, and Marx . . . to the modern labor problem yet written." Any member of the Western Federation of Miners who submitted fifteen paid subscriptions to the Miners' Magazine would receive a free copy of Mills book. ${ }^{50}$

Of course not all workers and socialists were sufficiently literate to take advantage of the numerous works on science and socialism issuing forth from printing presses. But literacy was not a prerequisite for coming into contact with science. There existed within the socialist movement something akin to the "movement culture" that Lawrence Goodwyn has found central to populism: a network of lectures, debates, readings, discussion groups, and meetings designed to educate the faithful. ${ }^{51}$ The socialist "movement culture" included a healthy dose of scientific information.

Socialist lecturers criss-crossed the United States speaking to anyone who would listen to them in theaters, open-air meetings and on street corners in an attempt to convince those present that they should be socialists. ${ }^{52} \mathrm{Or}$, if those assembled were already confirmed in the creed, then the lecturers tried to deepen their understanding of the finer points of socialism and science. Obviously the physical setting and sophistication of the audience often determined the content of the talk. As Arthur M. Lewis noted in his manual for socialist orators, The Art of Lecturing (1907), street-corner meetings were hardly conducive to the development of a complex theme such as the relationship between socialism and modern science. ${ }^{53}$ But, as Lewis loved to recall, a speaker might on occasion take advantage of a situation and win a telling victory by invoking his knowledge of science. Debating before a picnic crowd in Tillamook City, Oregon, Lewis' opponent Judge Hardy contended that science refuted socialism. The judge cited Darwin's struggle for existence 
as fundamentally opposed to the socialist conception of cooperation. Todrive home his thesis, the judge pointed to the surrounding grass and stated that each blade of grass, in order to reach perfection, must struggle with other. blades of grass. Lewis remembered that the judge's argument from science created "a great impression on the crowd." Not to be outdone, especially when scientific interpretation was involved, Lewis singled out the ubiquity of yellow weeds in the area as an indication that the best did not survive in an undirected, noncooperative struggle for existence. His interpretation of a collectivist view of Darwinism, based upon his reading of Peter Kropotkin's Mutual Aid, won the debate; its effect upon the crowd "was electrical and the applause spontaneous." 54

Scheduled debates and lectures were central to the socialists' "movement culture" and agitational activity. Eugene Debs thought that lectures on science were "an incalculable good to the party and movement." 55 If Chicago is taken as an example, then one can gain a sense of the popularity of lectures on science. Large crowds attended the Garrick Theater on Sunday mornings to hear socialist orators. It was here that over 3,000 heard Arthur M. Lewis debate "Darwinism versus Socialism" with M.M. Mangasarian. Lewis contended, not atypically, that "Darwinism is not opposed to socialism. All students of the socialist philosophy rely upon Darwinian theory for support of their doctrine." 56 While the topics covered by lecturers spanned a widerange of subjects, lectures such as Dr. S.A. Knopfnagel's on "The Origin of Science and Philosophy" were far from uncommon. ${ }^{57}$ In fact, overflow crowds were reported when Arthur Lewis devoted his 1906 lecture series to science topics, lecturing on Darwinian natural selection, Weismann's rejection of the theory of the inheritance of acquired characteristics, and DeVries' mutationstheorie. If the reports featured in the Chicago socialist press were accurate, then socialist lectures on science commanded large and enthusiastic audiences. ${ }^{58}$

Just how large and enthusiastic the working-class audience was for socialist science is not easily discerned. Circulation figures for the Kerr Publications are simply unavailable, although the volumes did go through numerous editions and did make a profit for the company. As noted earlier, Mills' The Struggle for Existence sold nearly half a million copies. In addition, socialist and workers' lending libraries carried books on science that were regularly loaned out to workers. ${ }^{59}$

The books on science did, perhaps, satiate what historians of the immigrant experience have called the newcomers' "hunger for knowledge." ${ }^{60}$ Nowhere was this hunger greater than among the radical Jewish immigrants who populated New York's Lower East Side. And, not surprisingly, they showed a great enthusiasm for science and philosophy. Later a leading socialist and editor of the Jewish Daily Forward, Abraham Cahan as a poor and hungry young man "scraped together the money" and bought a copy of Herbert Spencer's First Principles which gave him a scientific understanding of all phenomena. ${ }^{61}$ When he published the first issue of Di tsukunft (The Future) 
in 1892, Cahan tried to convince his readers that Darwinian theory held revolutionary implications for all science, philosophy, and life in general ${ }^{62} \mathrm{~A}$ young Rumanian immigrant, Marcus Ravage, remembered sweatshop discussions of Spencer and philosophy; he was immediately "impressed by the books workers read and the lectures they attended." 63

Working-class interest in science was not confined to the heady and precocious atmosphere of the Lower East Side; in the miswest as well workers encountered science. Coal miner Louis Duchez, who died at twenty-seven, was remembered as an inveterate reader who "before he was twelve ... was delving into Darwin and Huxley and Wallace." 64 As a young autoworker in Lorain, Ohio in 1908, Wyndham Mortimer recalled reading Ernest Untermann and Mills' Struggle for Existence as part of his life-long process of self-education. ${ }^{65}$ In Chicago, the songwriter of the Wobblies, Ralph Chaplin, switched from devouring "weekly penny-dreadfuls" to the works of "Darwin, Huxley, Spencer and other scientists and philosophers." 66

Unfortunately, while references to such encounters abound in the reminiscences of workers, the discussions rarely reveal the excitement and depth of their initial confrontation with science. For some, the results were, no doubt, staggering. "By the time I was bar mizvah," journalist I.F. Stone remembered, "I had read Herbert Spencer's First Principles and become an atheist." ${ }^{67}$ According to Jack London's daughter, her father "gobbled" Darwin and Spencer "in one excited reading." 68 Jack London recreated the fervor of his encounter with Spencer through his fictional alter-ego Martin Eden. After failing miserably to understand Spencer, Martin, now well grounded in algebra and physics, tries him once again. He reads First Principles all night, through the morning and the entire afternoon. Martin finds illumination as Spencer gives unity to the universe; "there was no caprice, no chance. All was law." Martin begins immediately to draw up lists of "incongruous things" and seeks to uncover their essential unity. In the end, "the more he [Martin] knew, the more passionately he admired the universe, and life, and his own life in the midst of it all." 69

Such excitement and a general socialist desire to disseminate scientific information declined precipitously in the 1920 s. This may be due to a general waning of American interest in science but the reasons may lie elsewhere. Certainly American Marxists had trouble incorporating the discoveries of modern physics into a dialectical materialist philosophy. ${ }^{70} \mathrm{But}$ the need to popularize science and to base Marxism upon a language of science had diminished, because after the Bolshevik seizure of power in 1917 American theorists finally had a model of a successful revolution. The revolution allowed Americans to jettison their analogies between Marxist theory and natural science and to replace them with the more powerful and current example of a "scientific" revolution led by that scientist of revolution, as they liked to say, the practical engineer Lenin. ${ }^{71}$ Even with the revival of radicalism in 1930s America, the Marxist and working-class interest in science was only a mute echo of the tones heard earlier. The practical experiment of the Soviet 
Union was the main subject for Marxist discourse along with the practical means for engineering a similar revolution in America. In effect the impetus to disseminate the scientific discoveries of the age had vanished and with it declined the desire to educate a working-class audience to a literature outside the scope of Marxist canons of revolutionary theory and practice.

\section{NOTES}

1. On the American idea of progress and how it subsumed science within its embrace, see Arthur Ekirch, The Idea of Progress in America, 1815-1860 (New York, 1972,) p. 106 passim; Rush Welter, "The Idea of Progress in America," Journal of the History of Ideas 41 (June, 1955):401-15.

2. Quoted in J.C. Levenson, "Henry Adams and the Culture of Science," in Studies in American Culture: Dominant Ideas and Images, ed. by Joseph J. Kwiat and Mary C. Turpie (Minneapolis, MN, 1960), pp. 123-138.

3. On the popularity of Spencer and his doctrines, Richard Hofstadter remains useful. See Social Darwinsim in American Thought (rev. ed., Boston, 1962), pp. 31-50.

4. Oliver Wendell Holmes to Morris R. Cohen, Feb. 5, 1919 in Leonora Cohen Rosenfield, Portrait of a Philosopher: Morris R. Cohen in Life and Letters (New York, 1962), p. 321.

5. On science as normative, see Edward Lurie, "Science in American Thought," Journal of World History 8 (1965):641,638-65. Also, David A. Hollinger, Morris R. Cohen and the Scientific Ideal (Cambridge, 1975), p. 58.

6. Reproduced in F.O. Matthiessen, The James Family (NY, 1947), p. 42.

7. John M. Coulter, Mission of Science in Education (Ann Arbor, 1900), p. 14.

8. Charles Rosenberg, No Other Gods (Baltimore, 1976), pp. 1-21.

9. Thomas L. Haskell, The Emergence of Professional Social Science (Urbana, 1977), p. 73; Barton J. Bledstein, The Culture of Professionalism (NY, 1976).

10. Donald M. Scott, "The Popular Lecture and the Creation of a Public in Mid-Nineteenth-Century America," JAH 66 (March, 1980):791-809.

11. Margaret W. Rossiter, "Benjamin Silliman and the Lowell Institute: The Popularization of Science in Nineteenth-Century America," New England Quarterly 44 (Dec. 1971):602,602-26; George Daniels, Science in American History: A Social History (NY, 1971), pp. 153-162. Hyman Kuritc, "The Popularization of Science in Nineteenth-Century-America," History of Education Quarterly 21 (Fall, 1981):259-274.

12. Bledstein, 77-79.

13. Charles M. Haar, "E.L. Youmans: A Chapter in the Diffusion of Science in America," Journal of History of Ideas 9 (April, 1948):193-213; William E. Leverette, Jr., "E.L. Youmans' Crusade for Scientific Autonomy and Respectability," American Quarterly 12 (Spring, 1965):12-32. Youmans' quote is in Hofstadter, p. 31.

14. Youmans, "Purpose and Plan of Our Enterprise," Popular Science Monthly l (May, 1872):113-15.

15. Haar, 200.

16. Ronald C. Tobey, The American Ideology of Natural Science, 1919-1930 (Pittsburgh, PA 1971), p. 12; Daniel J. Kevles, The Physicists (N.Y., 1978), pp. 96-97.

17. Tobey, 3-11; Charles W. Haywood, "Scientists and Society in the United States, 1900-1940. Changing Concepts of Social Responsibility," (Ph.D. diss., The University of Pennsylvania, 1954), pp. 6-12.

18. Tobey, 3. The best examination of Lippmann's scientism is presented by David Hollinger, "Drift and Mastery," American Quarterly 29 (Winter, 1977):463-475.

19. The influence of SPA intellectuals is discussed by Paul Buhle, "Intellectuals in the Debsian Socialist Party," Radical America 4 (April, 1970):35-61. Also, William I. Gleberzon, "Intellectuals and the American Socialist Party, 1901-1917," Canadian Journal of History 11 (April, 1976):43-68.

20. For the mass appeal of the SPA, see the standard treatments: James Weinstein, Ambiguous Legacy (NY, 1975), p. 7; The Decline of Socialism in America, 1912-25 (NY, 1967); David A. Shannon, The Socialist Party of America (Chicago, 1967); Ira Kipnis, The American Socialist Movement, 1897-1912 (NY, 1952); and James R. Green, Grass-Roots Socialism: Radical Movements in the Southwest, 1895-1943 (Baton Rouge, 1978).

21. Green, xi.

22. Lewis, An Introduction to Sociology (Chicago, 1912), p. 191.

23. Agitator I (Nov. 15, 1910): 2.

24. Masses 3 (March, 1912):18. 
25. The editorial was probably written by Algie M. Simons. International Socialist Review 6 (Sept., 1905): $176,178$.

26. An excellent discussion of Marx's and Engels' views on science will be found in Loren Graham, Science and Philosophy in the Soviet Union (NY, 1972), pp. 24-68.

27. Marx and Engles, Selected Correspondence, 1846-1895, trans. Dona Torr (NY, 1942), p. 125. Gaylord Wilshire, "The Mutation Theory Applied to Socialism," Wilshire's Magazine 8 (Sept., 1905):304.

28. Wilshire, "The Mutation Theory," 304.

29. John Spargo, Karl Marx: His Life and Work (NY, 1910), p. 323.

30. Joseph E. Cohen, Socialism of Students (Chicago, 1912), pp. 88-89.

31. The general socialist response to DeVries is covered by Diane B. Paul, "Marxism, Darwinism and The Theory of Two Sciences," Marxist Perspectives no. 5 (Spring, 1979):125-126. Typical of such analyses were Gaylord Wilshire, "The Mutation Theory," 304; William J. Ghent, Socialism and Success (NY, 1910), p. 48.

32. Simons, "Evolution by Mutation," International Socialist Review 6 (Sept. 1905):175.

33. Irving Howe, World of Our Fathers (NY, 1976), p. 246; David Hollinger, Morris R. Cohen, p. 58.

34. Hollinger, Morris R. Cohen, p. 58.

35. Lewis, Introduction, p. 126.

36. See "Publisher's Reports" in the International Socialist Review, esp. 12 (Feb., 1912):440-41; 4 (Feb. 1904):509-12; 4 (Sept., 1903):188-91; 4 (Dec. 1903):382-84.

37. Engels, Socialism: Utopian and Scientific (1900); Kautsky, The Social Revolution (1902); Liebknecht, Karl Marx: Biographical Memoirs (1901).

38. International Socialist Review 5 (May 1905):638-39.

39. Boelsche, The Evolution of Man (Chicago, 1905), pp. 5-7. On Boelsche, see Alfred Kelly, The Descent of Darwin: The Popularization of Darwinism in Germany, 1860-1914 (Chapel Hill, 1981). The other initial works in the series, all published in Chicago by Herr, were Boelsche, The Triumph of Life (1906); M. Wilhelm Meyer, The End of the World (1906); Ernest Untermann, Science and Revolution (1905); E. Teichman, Life and Death (1906); R.H. France, Germs of Mind in Plants (1905).

40. Boelsche, Evolution, pp. 48-50, 54, 152.

41. "Books on Socialism, Modern Science, etc." Supplement to France, Germs, p. 6.

42. Simons, Translator's Preface to France, Germs, pp. 5-6.

43. Moore, The Law of Biogenesis (Chicago, 1914), p. 17.

44. Marcy, "Introduction," 11-13.

45. Comrade 4 (Jan. 1905): 19.

46. Chicago Weekly Socialist 6 (Dec. 15, 1906):2..

47. Masses 1 (Jan. 1911):14.

48. Oscar Ameringer, If You Don't Weaken: The Autobiography of Oscar Ameringer. (NY, 1940), p. 268.

49. Mills is discussed in Green, Grass-Roots Socialism, pp. 41-2.

50. Miners' Magazine 6 (Jan. 5, 1905):1.

51. Lawrence Goodwyn, Democratic Promise: The Populist Movement in America (NY, 1976).

52. The spirit of street-corner meetings is captured by Charles Leinenweber, "Socialists in the Streets: The New York City Socialist Party in Working Class Neighborhoods, 1908-1918," Science and Society 41 (Summer, 1977):152-71.

53. Lewis, The Art of Lecturing (Chicago, 1907), pp. 77-78.

54. Lewis, "The Yellow Weed of Sleepy Hollow," Chicago Daily Socialist 1 (April 23, 1907):4.

55. Chicago Daily Socialist 2 (Jan. 3, 1908):2.

56. Ibid., 1 (June 4, 1907):3.

57. Ibid., l (March 22, 1907):2.

58. Ibid., I (Feb. 4, 1907):3. Lewis' lectures on science were collected and published as Evolution: Social and Organic (1906).

59. International Socialist Review 7 (July, 1906):61; 6 (Feb. 1906):510-11.

60. Howe, p. 225. Also, Timothy Smith, "Immigrant Social Aspirations and American Education," American Quarterly 21 (Fall, 1969):523-43.

61. Cahan, The Education of Abraham Cahan trans. Leon Stein, Abraham P. Conan, Lynn Davison (Philadelphia, 1967), pp. 369-70. Cohan probably captured his own excitement in reading through fictional characters such as David Levinsky. See Cahan, The Rise of David Levinsky (NY, 1960), pp. 282-83.

62. Theodore M. Pollack, "The Solitary Clarinetist: A Critical Biography of Abraham Cahan, 1860-1917," (Ph.D. Diss., Columbia University, 1959), p. 163.

63. Marcus E. Ravage, An American in the Making (NY, 1917), pp. 144-147. 
64. Robert Johnstone Wheeler, “Louis Duchez, A Tribute," International Socialist Review 12 (Oct., 1911): 231-34.

65. Wyndham Mortimer, Organize!: My Life as a Union Man ed. Leo Fenster (Boston, 1971), p. 33.

66. Ralph Chaplin, Wobbly: The Rough-and-Tumble Story of an American Radical (Chicago, 1948), pp. 46,51

67. Quoted in Philip Nobile, Intellectual Skywriting: Literary Politics and the New York Review of Books (NY, 1974), p. 162. Max Eastman had a similar reaction after reading Spencer. See Milton Cantor, Max Eastman (NY, 1970), p. 22.

68. Joan London, Jack London and His Times (Seattle, Wash., 1968), pp. 206-09.

69. London, Martin Eden (NY, 1909), pp. 106-109.

70. See Will Herberg's series of articles on this problem which appeared in Revoluntionary Age 2 (Dec. 13, 1930):3; (December 2, 1930):3; (December 27, 1930):3; (April 4, 1931):3-4. For a further critique of the earlier socialist apotheosis of Darwinism, see Herberg's “Darwinism and Marxism," Workers Age 1 (May 7 , 1932):3.

71. The fullest expression of this point of view is to be found in Max Eastman, "A Statesman of the New Order," Liberator 1 (Sept. 1918):10. He continued this line of argument in Since Lenin Died (London, 1925) and Marx and Lenin: The Science of Revolution (New York, 1927). 